\title{
An Empirical Examination of the Export-Led Growth Theory Regarding Georgia
}

Davit Belkania, Ph.D.

Mehman Karimov, Ph.D.

Kaposvár University, Faculty of Economic Science

\begin{abstract}
This paper aims to justify the validity of the export-led growth hypothesis (ELG) for the transition economy like Georgia. The ELG theory implies the acceleration of an economic growth through the market openness in exchange for market expansion. The concept of the work lies in the following assumptions: Firstly, as a transition country, Georgia should prioritize private sector driven and export-led growth economy and secondly, the European integration process is the unprecedented opportunity for Georgia regarding export market expansion. The paper covers the time from 1990 to 2016; Engle-Granger cointegration and Granger causality tests were employed to trace the validity of the ELG hypothesis. The results confirmed the existence of at least one cointegration vector, as well as the bidirectional causality between economic growth and export, thus landed support on the validity of the ELG hypothesis regarding Georgian economy.
\end{abstract}

Keywords: Economic growth, export, Export-led growth hypothesis, Georgia

\section{Introduction}

An economic development strategy varies depending on a country background and its role in the global economy. It is the common practice that for small countries like Georgia, consumption is limited as it is a market volume. This condition creates a high dependency on external markets. Over the years, as the economy is getting more advanced, the dependence on the foreign market increases correspondingly. Considering the European integration process of Georgia that opens the doors to a whole new market, the export-led growth hypothesis (ELG) can boost the economic growth through "reaping" the trade benefits in terms of comparative advantage. In addition, implementation of the ELG theory can enhance the inflow of foreign direct investments (FDI) in a country, thus increasing productive capacity and capital accumulation of the nation (Salisu \& Sapsford 1996).

During last two decades Georgia developed sufficient base of the economic legislation to implement the outward oriented growth strategy. Georgia is a post-soviet state which is in a transition process from a centrally planned economy to a market economy with GDP per capita of 3864.6 USD. After undergoing a set of structural changes to develop the market based institutional framework, Georgian economy started growing rapidly. In 2007 annual GDP growth reached $12.34 \%$ that was the exceptional record for the country. ${ }^{1}$ In the World Bank accounts, Georgia is set as the exemplary model regarding successful economic transformation.

An Association Agreement and DCFTA (Deep and Comprehensive Free Trade Areas) that took place in 2014, is the remarkable economic phenomenon for the country. DCFTA serves as the main stimulus for the promotion of the ELG theory. It refers to the extended market access through the harmonization of a national and EU regulations, as well as the reduction of the trade barriers to some extent. By signing these agreements, Georgia is able to explore 500 million European market; Correspondingly diversifying the export market and raising the incentives to invest in productivity improvements (Juvenal \& Monteiro 2013). ${ }^{2}$

\footnotetext{
1 Gross Domestic Product. National Statistics Office of Georgia. http://www.geostat.ge/index.php?action=page\&p_id=119\&lang=eng 2 Juvenal \& Monteiro (2013). Export Market Diversification and Productivity Improvements. http://citeseerx.ist.psu.edu/viewdoc/download?doi=10.1.1.296.5533\&rep=rep1\&type=pdf
} 
Currently, decomposition of Georgia's export market looks as following: Russia remains the biggest market for Georgia with the $12.9 \%$ share; The second largest export market is Turkey $12.6 \%$ coming with Azerbaijan $9.1 \%$, USA 6.7\%, and Romania $6.6 \%$. As for the export by country groups, EU covers $28.8 \%$ of the Georgian total export, CIS countries $36.3 \%$ and others $34.9 \%$ respectively.

Nowadays, EU is the largest host market for agricultural products that are produced by developing or transition countries. Therefore, Georgian agricultural production is the additional aspect to be considered at the national level. As an agrarianoriented country, Georgia has a significant rural population. The employment in agriculture as the percentage of total employment averaged 40\% during 1990-2016. ${ }^{1}$ A contribution of the agricultural sector in GDP is ranging from 8 to $9 \%$. Dependence of Georgia's economic performance on the agricultural sector is undeniable.

Recent OECD (The Organization for Economic Cooperation and Development) study showed that Georgia's comparative advantage in agriculture ranks 15th out of 193 countries. In a study of global wine markets, Georgia's revealed comparative advantage in wine ranks second on a list of 13 major wine exporting countries. ${ }^{2}$

The list of the product categories in which Georgia revealed comparative advantage from 2008 to 2017 include: ferro alloys, motor-cars, copper ores, live animals, pharmaceutical products, beverages, wine, vegetable plaiting material and etc. Furthermore, the export intensity index of Georgia with EU indicates that Georgia is exporting less than we should expect. Hence, there is considerable potential to stimulate the export earnings through prioritization of agricultural sector.

\section{Literature review}

Although a relationship between trade and growth is quite "mature" topic in economics, the general dispute still exists. The emergence of the ELG theory is dated back to post world war two period. By the $80^{\text {th }}$ of the last century, the ELG hypothesis reached a general consensus in the academic field regarding its effectiveness. During this period, advocates of ELG theory seemed to be the winners of the inward-outward oriented policy game in trade and economic growth. Later on, while the economic growth theorists continued to deal with general trade-economic growth concepts, interestingly, a number of country-specific empirical researches were conducted, which did not support the "conventional wisdom" of ELG theory. For instance, contrary to Chinese experience with ELG growth model, Mexico has not recovered its strong performance of 1960-1980 [Thomas I. Palley 2011]. In the empirical research regarding exports, growth, and causality in developing countries conducted by Woo S. Jung and Peyton J Marshal, only in 4 cases out of 37 was there evidence that supported the export-led hypothesis (Indonesia, Egypt, Costa Rica, and Ecuador). Similar results were presented in Henriques and Sadorsky (1996), Jung and Marshal (1985) etc.

Herman Daly (1999) called globalization via ELG the new philosopher's stone of the IMF-IBRD-WTO alchemists and criticized ELG in terms of low wages, poor working class, and deteriorated environment.

Despite the controversy that arose from the number of country-specific empirical researches, ELG theory still persists on its effectiveness. As so, despite the theoretical dispute regarding emerging new models, it is important to conduct the empirical examination to reduce the gap between theory and practice. Till now, the economic growth is thought to be an essential goal for the countries' wellbeing. Increasing export is considered as the important stimulus for economic growth. Developing countries try to reach high economic growth through more trading. For low-income countries, agriculture plays a vital role in increasing export to reach economic development. Mostly, theoretical sources consider export as a growth engine and with reference to low-income countries, agriculture is an essential part of increasing the export.

As Francisco F. Ribeiro Ramos remarked: Export, as a main determinant of the production and employment growth according to export-led growth theory (ELG), is supported by the following reasoning: Firstly, the export growth is escorted by the expansion of production and employment regarding export multiplier that operates like the investment multiplier of Keynes; Secondly, the foreign exchange enhances the importation of capital goods, successively increase the production ability of a country; Competition in the exports markets leads to technological progress in terms of production, as well as, economies of scale (Ramos 2001).

\footnotetext{
${ }^{1}$ International Labor Organization. Employment by sector -- ILO modelled estimates, May 2018. Georgia.

2 Cramon-taubadel, S. Von. (2014). Georgia's agricultural exports, (November)

http://georgien.ahk.de/fileadmin/ahk_georgien/Publikation/Georgias_agriculture_exports.pdf
} 
An effectiveness of export in economic growth is mentioned in the works of Robert F. Emery. He argued that there is a causal relationship between the two and that this relationship is one of interdependence rather than of unilateral causation, but that it is mainly a rise in exports that stimulates an increase in aggregate economic growth rather than vice versa (Robert F. Emery 1967).

Peter C.Y. Chow, Gershon Feder and Rostam M. Kavoussi presented empirical results, which showed that "for the small open economies the development of manufacturing industries and export growth have causal relationships. It means that they are interdependent in the development process. The export growth in developing countries can expand their limited domestic markets and contribute to the economies of scale necessary for industrial developments. Furthermore, export growth integrates domestic economy with regional and/or global economies thereby expanding the dimension of competition to international markets. Competition promotes resources reallocations in developing countries as they transform from less productive farming sector to relatively more productive manufacturing sector. Therefore, factor productivities are improved through export growth" (Peter C.Y. Chow 1987).

In his work "Export expansion, growth and the level of economic development" Demetrios Moschos showed that the positive effect of the export on economic growth is limited for 'advanced economies' but on the contrary, the evidence indicates that among 'less advanced developing economies' output growth is mainly influenced by export expansion and capital formation, its response to labor growth being highly insignificant (Moschos 1989).

Furthermore, Majid Mahmoodi and Elahe Mahmoodi provided the evidence of long-run causality from export and FDI to economic growth and long-run causality from economic growth and export to FDI. Thus, as Gerald M. Meier remarked, export expansion leads to a reduction of the unemployment rate as well as increased domestic saving/investment, by this enhancing the inflow of factor inputs regarding the export sector.

Both, empirical and theoretical scientific literature reflects the bipolar nature of the ELG hypothesis. The effects of export on economic growth are derived through the positive impact on the resource allocation, economies of scale, the inflow of the foreign direct investment, labor force skills, employment, and capital formation. Conducting the empirical analysis is essential in this case to provide a solid argument for ELG effectiveness.

\section{Methodology}

\subsection{Model specification}

This paper uses a Solow-Swan growth model which derived from the neoclassical production function framework, commonly referred to Cobb-Douglas kind. According to the model the output is calculated by the interaction of two factors of production, labor force and capital.

Originally the model was designed by Robert Solow and Trevor Swan in 1956. Due to its flexibility and simplicity, the SolowSwan model can facilitate various extensions, thus, it became the basis of multiple mathematical formulations. Similarly, our model uses the following production function:

$Y=f(L, K)$

Correspondingly, the formula is expanded by adding total export:

$G D P_{t}=f\left(L F_{t}, C A_{t}, E X_{t}\right)$

By taking natural logarithm on the variables we discarded the differences in the units of measurements and minimize the gap between them:

$\operatorname{lnGDP_{t}}=\beta_{0}+\beta_{1} \ln L F_{t}+\beta_{2} \ln C A_{t}+\beta_{3} \ln E X_{t}+\varepsilon_{t}$

$L G D P_{t}, L L F_{t}, L C A_{t}$, and LEX $X_{t}$ are natural logarithm of the gross domestic product, labor force, capital, and export respectively; $\varepsilon_{t}$ represents the error term; $\beta_{0}$ is the constant and $\beta_{1}, \beta_{2}, \beta_{3}$ are the coefficients to be estimated.

\subsection{Specification of the variables}

This paper uses the secondary time-series data (from 1990 to 2016) collected from the National Statistics Office of Georgia and World Bank Group. The following variables were used for the empirical analysis: 
GDP - Gross Domestic Product. GDP is expressed in terms of total value of goods and services produced in an economy within a year (inflation adjusted).

EX - Total Export is the sum of the goods and services produced in a country and sold abroad to foreign countries/citizens.

$C A$ - Gross Capital Formation is the total value of the gross fixed capital formation, changes in the inventories and acquisitions less disposals of valuables for a unit or a sector. ${ }^{1}$

$L F$ - Total Labor Force or currently active population, comprises all the persons who fulfill the requirements for inclusion among the employed or the unemployed during a specified brief reference period. ${ }^{2}$ It will reflect the effect of LF on GDP growth.

\subsection{Research methods}

The method selection process was guided by the stationarity level of the variables and sensitivity of the co-integration tests regarding the time span. The level of stationarity is important to avoid spurious regression. ${ }^{3}$

The stationarity check of the variables presented in this paper was performed through the Augmented Dickey-Fuller test (ADF). ADF test procedure is similar to standard Dickey-Fuller (DF) test (equation 4). Difference is that in ADF test we are augmenting the DF test by the lagged values of the dependent variable (equation 5):
$\Delta Y_{t}=\beta_{0}+\delta Y_{t-1}+\mu_{t}$
(4) DF with drift
$\Delta Y_{t}=\beta_{0}+\delta Y_{t-1}+\delta_{1} \Delta Y_{t-1} \ldots+\delta_{p-1} \Delta Y_{t-p+1}+\mu_{t}$
(5) ADF with drift

The null hypothesis of the test is that series contain the unit root, therefore it is non-stationary and alternative hypothesis states that the series does not contain the unit root and it is stationary. If the $P$ value is less than $5 \%$, we can reject $H_{0}$ and accept $H_{1}$ of stationarity of the series.

Unlike other cointegration tests, Engle-Granger is less sensitive to small data sample. As long as our data covers the period from 1990 to 2016, by this having at most 27 observations, the Engle-Granger co-integration test was employed to check the validity of the ELG hypothesis.

In general, Engle-Granger co-integration is a two-step test which requires series to be integrated of the same order. Correspondingly, if the series are integrated of order 1 , but the error term in this relationship tends to be stationary $I(0)$, then the series are cointegrated. ${ }^{4}$ Engle-Granger co-integration is the residual based test (equation 6 ) which uses the following equation (7) for the co-integration procedure:

$\varepsilon_{t}=Y_{t}-\beta_{0}-\beta_{1} X_{t}$

$\Delta \varepsilon_{t}=\mu+\varphi \varepsilon_{t-1}+\varepsilon_{t}$

The null hypothesis of the test states that there is no co-integration relationship $\left(H_{0}=(\varphi=0)\right)$ and alternative hypothesis: $H_{1}=$ Existence of the co-integration $(\varphi \neq 0)$.

The last step of our empirical analysis deals with the causality check of economic growth and total export. Hence, the Granger causality test was employed. This test refers to the augmentation of the autoregression of the particular variable by including lagged values of another variable to check if it adds explanatory power to the regression. Mathematical formulation of the Granger causality test is as follows:

\footnotetext{
${ }^{1}$ Glossary of statistical terms - Gross Capital Formation https://stats.oecd.org/glossary/detail.asp?ID=1158

2 OECD - The Organization for Economic Co-operation and Development, Glossary of Statistical Terms. https://stats.oecd.org/glossary/detail.asp?ID=2719

3 Stationarity - The Central Concept in Time Series Analysis. Andreea-Cristina Petrică. https://www.ermt.net/docs/papers/Volume_6/1_January2017/V6N1-107.pdf

${ }^{4}$ Co-Integration and Error Correction: Representation, Estimation, and Testing - Robert F. Engle; C. W. J. Granger. http://www.ntuzov.com/Nik_Site/Niks_files/Research/papers/stat_arb/EG_1987.pdf
} 
$Y_{t}=a_{0}+\alpha_{1} y_{t-1}+\alpha_{2} y_{t-2}+\ldots+\alpha_{m} y_{t-m}+b_{p} x_{t-p}+\ldots+b_{q} X_{t-q}+e r r o r t$.

The null hypothesis of the test states that $y$ does not Granger cause $x$ and vice versa; in other words: No explanatory power added by the $x$ 's lagged values.

\section{Econometric analysis}

\subsection{Stationarity check and order of integration}

As the precondition of the Engle-Granger co-integration test, the variables must be integrated of order one. Therefore, stationarity check was performed on all the variables by using the Augmented Dickey-Fuller (ADF) unit root test. Preexamination of the raw data indicated the distortion from the endemic post-Soviet affects in terms of huge time-series shifts from 1990 to 1991, thus we eliminated two observations. In this regard, the elimination of the observations helps us to estimate the model for the post-soviet state; 'Blank page' for the country of Georgia.

The results showed that observed series are non-stationary at levels, as far as we can't reject the null hypothesis of nonstationarity: T-statistics are less than critical values at $5 \%$ level of significance and $P$-values of the corresponding variables are more than $5 \%$. After taking the first difference, the series became stationary (T-statistics $>$ Critical values at $5 \%$ and $\mathrm{P}$ values $<5 \%)$. Thus, the series appear to be integrated of order one $(I(1))($ See Table 1$)$.

Table 1. ADF unit root test results.

\begin{tabular}{lllll}
\hline Variables & InGDP & $\operatorname{lnLF}$ & $\operatorname{lnCA}$ & $\operatorname{lnEX}$ \\
\hline ADF at Level (T-Stat.) & -1.43 & -2.39 & -1.03 & -1.16 \\
Critical Values at 5\% (level) & -2.99 & -2.99 & -2.99 & -2.99 \\
Prob. at Level & 0.54 & 0.15 & 0.72 & 0.67 \\
\hline ADF at 1st Difference (T-Stat.) & -4.70 & -4.38 & -5.73 & -6.48 \\
Critical Values at 5\% (1st Diff.) & -3.00 & -2.99 & -3.01 & -3.01 \\
Prob. at 1st Difference & 0.001 & 0.002 & 0.000 & 0.000 \\
\hline
\end{tabular}

\subsection{Estimation of the long-run relationship}

The results of the ADF unit root test showed that all the series are integrated of order one. Thus, we can proceed to the estimation of the long-term relationship between economic growth (GDP) and total export (EX) by using the Engle-Granger cointegration test. The results of the test are presented below in Table 2:

Table 2. Engle-Granger co-integration test results.

\begin{tabular}{|c|c|c|c|c|}
\hline \multicolumn{5}{|c|}{ Step 1: Co-integrating regression } \\
\hline Dependent: InGDP & Coefficient & Std. error & T-ratio & P-value \\
\hline Constant & 9.44 & 3.890 & 2.427 & 0.024 \\
\hline Time & 0.024 & 0.003 & 7.35 & $4.21 \mathrm{e}-07$ \\
\hline $\operatorname{lnLF}$ & 0.557 & 0.265 & 2.098 & 0.0488 \\
\hline $\ln C A$ & 0.159 & 0.022 & 7.091 & $7.13 e-07$ \\
\hline $\ln E X$ & 0.079 & 0.020 & 3.806 & 0.001 \\
\hline Adjusted R-Squared & 0.98 & & & \\
\hline Durbin-Watson & 1.63 & & & \\
\hline \multicolumn{5}{|c|}{ Step 2: Testing for a unit root in residuals } \\
\hline \multicolumn{2}{|c|}{$\begin{array}{l}\text { model: }(1-L) y=(a-1)^{*} y(-1)+\ldots+e \\
\text { estimated value of }(a-1):-0.876719 \\
\text { test statistic: tau_c(4) }=-4.4093\end{array}$} & \multicolumn{3}{|c|}{ p-value: 0.002121} \\
\hline
\end{tabular}


The result presented in Table 2 confirms the existence of the cointegration between the GDP and Export. All the variables are statistically significant at most $5 \%$ level. As for export, $1 \%$ increase of total export increases economic growth by $0.079 \%$. Furthermore, The residuals tend to be stationary, as long as we can reject the null hypothesis of non-stationarity (Step 2 in co-integrating regression presented above: $p$-value $=0.002<0.05 \%$ ). Durbin-Watson value is close enough to ideal value and the adjusted R-squared is high ( $98 \%)$, meaning that the dependent variable was explained by $98 \%$.

\subsection{Post-diagnostic tests for Long-run relationship model}

\subsubsection{Autocorrelation test}

Autocorrelation is the process when the time-series data is influenced by its own lagged values. Thus, violating the underlying assumption of independence. Check for the autocorrelation was performed via LM test for autocorrelation. The null and alternative hypothesis of the test states the following: $H_{0}$ : No $A R(P)$ and $H_{1}: A R(P) . P=1$, as long as we are testing for the first order autocorrelation $(A R(1))$.

Table 3. Autocorrelation LM test results.

LM test for autocorrelation up to order 1. Null hypothesis: no autocorrelation

\begin{tabular}{l|l}
\hline Test statistic: LMF & 0.343064 \\
P-value $=P(F(1,20)>0.271537)$ & 0.564959
\end{tabular}

According to the test results, the series does not indicate the presence of the first order autocorrelation, as we can't reject the $H_{0}$ : Probability (0.564959) of the Test statistic with the value of 0.343064 is more than 0.05 (See Table 3 ).

\subsubsection{Heteroskedasticity test (White's test)}

To ensure the consistent results from the regression model, the residuals must indicate the constant variance, or homoscedasticity. In this regard, heteroskedasticity refers to the changing variance of the residuals.

Presence of the heteroskedasticity in the model violates the profound assumption of the homoscedasticity and can bias the regression results. Hence, we used the White's test for heteroskedasticity. Null hypothesis of the test states the absence of the heteroskedasticity. $H_{0}$ can be rejected if the probability value is less than $5 \%$ and vice versa.

Table 4. White's heteroskedasticity test results.

\begin{tabular}{l|l}
\hline White's test for heteroskedasticity. \\
Null hypothesis: heteroskedasticity not present \\
\hline Test statistic & 18.2068 \\
P-value $=P($ Chi-square $(14)>18.2068)$ & 0.197522 \\
\hline
\end{tabular}

The results of the White's test do not detect the presence of the heteroskedasticity, as we failed to reject the $H_{0}$ ( $P$ value $>5 \%$ ). Therefore, residuals seem to be homoscedastic.

\subsubsection{Normality of residuals (Shapiro-Wilk Test)}

Observing the residuals is the vital aspect of our statistical modeling. To check whether the residuals are well-behaved or not, we applied to Shapiro-Wilk Test. The $H_{0}$ of the test is that the sample is normally distributed. $H_{0}$ is rejected if the probability value is less than $5 \%$, thus accept the alternative hypothesis of non-normality.

Table 5. Shapiro-Wilk Test Results.

Shapiro-Wilk Test for normality of residual. Null hypothesis: Error is normally distributed

\begin{tabular}{l|l}
\hline Shapiro-Wilk W & 0.948424 \\
P-value & 0.230967 \\
\hline
\end{tabular}


The results of the test showed that the residuals are normally distributed, as we cannot reject the $\mathrm{H}_{0}$ of normality ( $\mathrm{P}$ value $=0.230967>0.05 \%$ ) (See Table 5).

\subsubsection{Structural stability of the parameters (CUSUM Test)}

We used CUSUM test to check the structural stability of the estimated parameters. The $H_{0}$ of the test states that parameters are structurally stable, against $H_{1}$ : Parameters are not structurally stable. If the test crosses the $95 \%$ confidence band even once, then the coefficients are not structurally stable.

\section{Graph 1. CUSUM test results.}

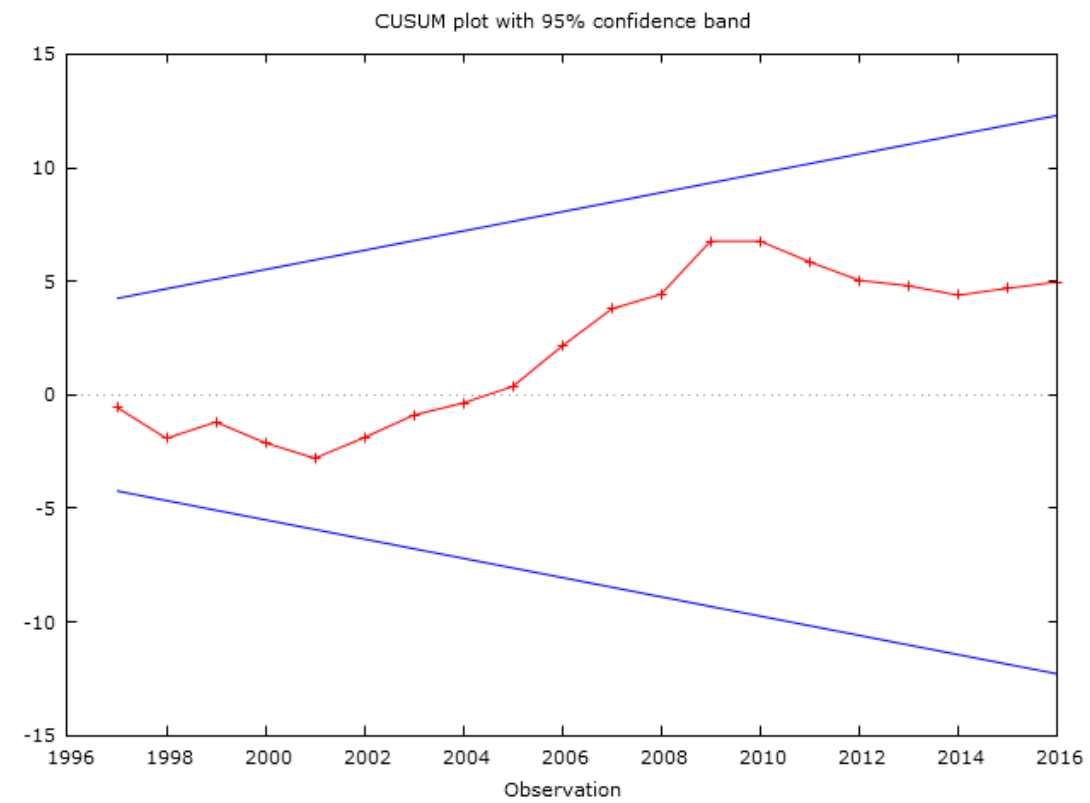

(Harvey-Collier t(19) $=1.10995$ with $p$-value 0.2809)

As we can see from the Graph 1 , crossing of the $95 \%$ confidence band is not detected, and P-value $=0.2809>0.05$, therefore, we accept the $H_{0}$ of structural stability of the coefficients.

\subsection{Causality check}

The last step of our econometric analysis deals with causality check. In the previous section, we showed the existence of the long-run relationship between economic growth and export. Thus, suggesting that there can be a causal relationship between the two. Performing the Granger causality test revealed the existence of bidirectional causal relationship from export to GDP and vice versa, as we can rejected both null hypothesis of no causality at $5 \%$ level of significance (See Table 6):

\section{Table 6. Granger causality test results.}

\begin{tabular}{lll}
\hline Null Hypothesis & F-Statistic & Probability \\
\hline InEX does not Granger Cause InGDP & 6.54 & 0.018 \\
InGDP does not Granger Cause InEX & 16.92 & 0.000 \\
\hline
\end{tabular}




\section{Conclusion}

This paper empirically examined the compatibility of the ELG hypothesis for the Georgian economy. To check the validity of the theory multiple econometric methods were employed namely Engle-Granger co-integration and Granger causality tests.

Although, current direction of the Georgian economy does not indicate strong signs of the export-driven economy, empirical results landed support to the ELG hypothesis by revealing the existence of the long-run co-integration relationship between economic growth and the export, as well as the bidirectional causality from export to GDP and vice versa. Thus, prioritization of the ELG theory as the main economic development strategy can boost the economic performance of the country. Due to the European integration process, Georgia has an opportunity to explore the new export market. Therefore, enhancing the economic growth in the long-run through increasing the export earnings.

An adoption of the outward-oriented growth model in Georgian economy can have multiple benefits: Besides the GDP growth, export expansion can stimulate the foreign direct investment (FDI) inflow, as well as the reduction of the unemployment and increase in domestic savings. To stimulate the rapid growth, economic policymaking should be directed towards the most productive sectors of the export production (like wine and agriculture) to reap the benefits of both, comparative advantage and increasing returns to scale.

There is no doubt that after changing a direction of the economic development strategy towards radical, outward-oriented growth, the results will reflect stronger support to the ELG hypothesis. Thus, farther empirical examination will be needed to trace the validity of the ELG theory. As for now, this article can serve as the preliminary results indicating the effectiveness of the ELG theory, even though it is not fully prioritized by the country.

\section{References}

[1] Anderson Kym (2013): Is Georgia next "new" wine exporting country? Journal of Wine Economics, Volume 8, Number 1. Pages 1-28.

[2] Balasubramanyam Vudayagiri N., Salisu M., Sapsford David (1996): Foreign direct investment in EP and IS countries. The Economic Journal, Vol. 106, No. 434 (Jan. 1996), pp. 92-105

[3] Bruton Henry J. (1970): The import substitution strategy of economic development. A survey of findings. Research Memorandum No. 27. Williamstown, Massachusetts.

[4] Chow Peter C.Y. (1987): Causality between export growth and industrial development. Journal of Development Economics. 55-63.

[5] De Mello Luiz R. (1999) Foreign direct investment-led growth: evidence from time series and panel data. Oxford economic papers, Oxford University Press 51, 133-151, 1999.

[6] Daly Herman E. (1999): Uneconomic growth: In theory, in fact, in history, and in relation to globalization. DigitalCommons@CSB/SJU, Clemens Lecture Series.

[7] Fosu A. K. (1990): Export composition and the impact of exports on economic growth of developing economies. Economics Letters, 34(1), 67-71.

[8] Feder Gershon (1983): On exports and economic growth. Journal of Development Economics, volume 12.

[9] Juvenal Luciana \& Paulo Santos Monteiro (2013): Export Market Diversification and Productivity Improvements: Theory and Evidence from Argentinean Firms. Research Division, Federal Reserve Bank of St. Louis, Working paper 2013-015A.

[10] Kavoussi Rostam M. (1984): Export expansion and economic growth. Journal of Development Economics. 241250.

[11] Moschos Demetrios (1989): Export expansion, growth, and level of economic development. Journal of Development Economics. 93-102.

[12] Meier Gerald M. (2000): Leading issues in economic development. Oxford university press, sixth edition. 
[13] Ramos Francisco F. Ribeiro (2001): Exports, imports, and economic growth in Portugal: evidence from causality and cointegration analysis. Elsevier, Volume 18, Issue 4, December, Pages 613-623.

[14] Reyes Jose-Daniel, Gonzalo Varela, and Miles McKenna (2014). Information for Export Survival: An Analysis of Georgian Export Performance and Survival in International Markets. The World Bank, (PREM).

[15] Taralashvili Tamar (2014): Foreign trade of Georgian agricultural products and existing potential of export to the European Union market. ACTA Scientiarum Polonorum, Oeconomia 13 (1) 2014, 123-134.

[16] Tyler W. G. (1981): Growth and export expansion in developing countries. Some empirical evidence. Journal of Development Economics, 9(1), 121-130.

[17] World Bank (1993), Product Cycle: The East Asian Miracle: Economic Growth and Public. Quarterly Journal of Economics, 80:190-207

[18] Yang Jie (2008): An Analysis of So-Called Export-led Growth. IMF working paper. WP/08/220, International monetary fund. 